\title{
Reply to the comments of Assine et al. (Comments on paper by M. Arai "Aptian/Albian (Early Cretaceous) paleogeography of the South Atlantic: a paleontological perspective")
}

\author{
Réplica aos comentários de Assine et al. (Discussão do artigo \\ "Aptian/Albian (Early Cretaceous) paleogeography of the South \\ Atlantic: a paleontological perspective" de M. Arai)
}

\author{
Mitsuru Arai ${ }^{1 *}$
}

I appreciate the comments from Mário Luis Assine and his co-authors (Assine et al. 2016), because scientific progress often occurs through forthright comments such as these. However, I would like to emphasize that "non-paleontologist specialists must accept paleontological data, even these data were apparently controversial, and must look for compatible explanation within their skills" (Arai 2011, p. 343 and 351). Geological models that fail to take account of very strong paleontological evidence clearly carry a high risk of failure. This happened in the case of Alfred Wegener's Theory of Continental Drift, which had the similarity of Gondwana fossils as one of its basic and compelling fundamentals: all other theories that did not adopt the plate tectonics concept were consequently abandoned. Thus, one of the affirmations of Assine et al. which must be rejected immediately is the existence of a drainage divide between the Araripe and Parnaíba basins at the time of sedimentation of the Codó (Parnaíba Basin) and Santana (Araripe Basin) formations, because of striking similarities among the fossil contents of these formations. If the aforementioned drainage divide actually existed, it would clearly constitute a biogeographic barrier inhibiting the development of similar biota in these basins (Cox \& Moore 2000, Lomolino et al. 2006). Assine et al. based their argument solely on paleocurrent measurements which supposedly indicated water flow to the south and southeast during Aptian time. However, the Rio da Batateira (= "Barbalha Formation" sensu Assine 2008) and Marizal formations, whence the measurements were derived, were not deposited in a typical fluvial system, but at the onset of the marine transgression. Clearly, these formations represent coastal sediments deposited under a transgressive regime. In this case, the cross-stratifications indicative of paleocurrents originated via flooding tide and are thus reliable pointers to the direction of the marine transgression (Fig. 1). Evidently, in the case of the regressive system, the stratifications produced by ebbing tide would be preserved preferentially, and they would signify flow direction essentially coincident with that of associated fluvial flow.

The Assine et al. reasoning is perfectly adequate in the case of the paleocurrent of the Exu Formation, which accumulated in a typical fluvial system flowing westward (Assine 1994). In this regard, the paleocurrent orientation indicates the presence of marine conditions to the west. The Araripe Group - comprising the Rio da Batateira (= "Barbalha"), Santana, Arajara (= "Araripina" sensu Assine 2008) and Exu formations - represents an entire transgressive-regressive cycle. Thus it is not conceivable to position the sea in completely different places at the beginning (to south) and the end (to west) of the cycle. Logically, a regressive sea always withdraws from a sedimentary basin through the same fluvial valley occupied previously

${ }^{1}$ Centro de Geociências Aplicadas ao Petróleo - UNESPetro, Instituto de Geociências e Ciências Exatas - IGCE, Universidade Estadual Paulista “Júlio de Mesquita Filho" - UNESP, Rio Claro (SP), Brazil.E-mail:mitsuru.arai@gmail.com

*Corresponding author.

Manuscript ID: 2015046B. 
by a flooding transgressive sea. The incontrovertible evidence that the interior sea regressed through the Parnaíba and São Luís basins is the decreasing age of the Itapecuru Group from south (e.g., Aptian/Albian in Querru outcrop: Ferreira et al. 2011, 2016) to north (e.g., Cenomanian in Ponta do Farol: Carvalho \& Pedrão 1998) (Fig. 2).
Another assertion stated by Assine et al. is that marine strata directly overlie crystalline basement on the Araripe Basin's western border. This would apply only if the main valley of the seaway was directed east-west, as suggested by the orientation of the basin's present-day greater axis. Nevertheless, the valley occupied by the seaway actually had a

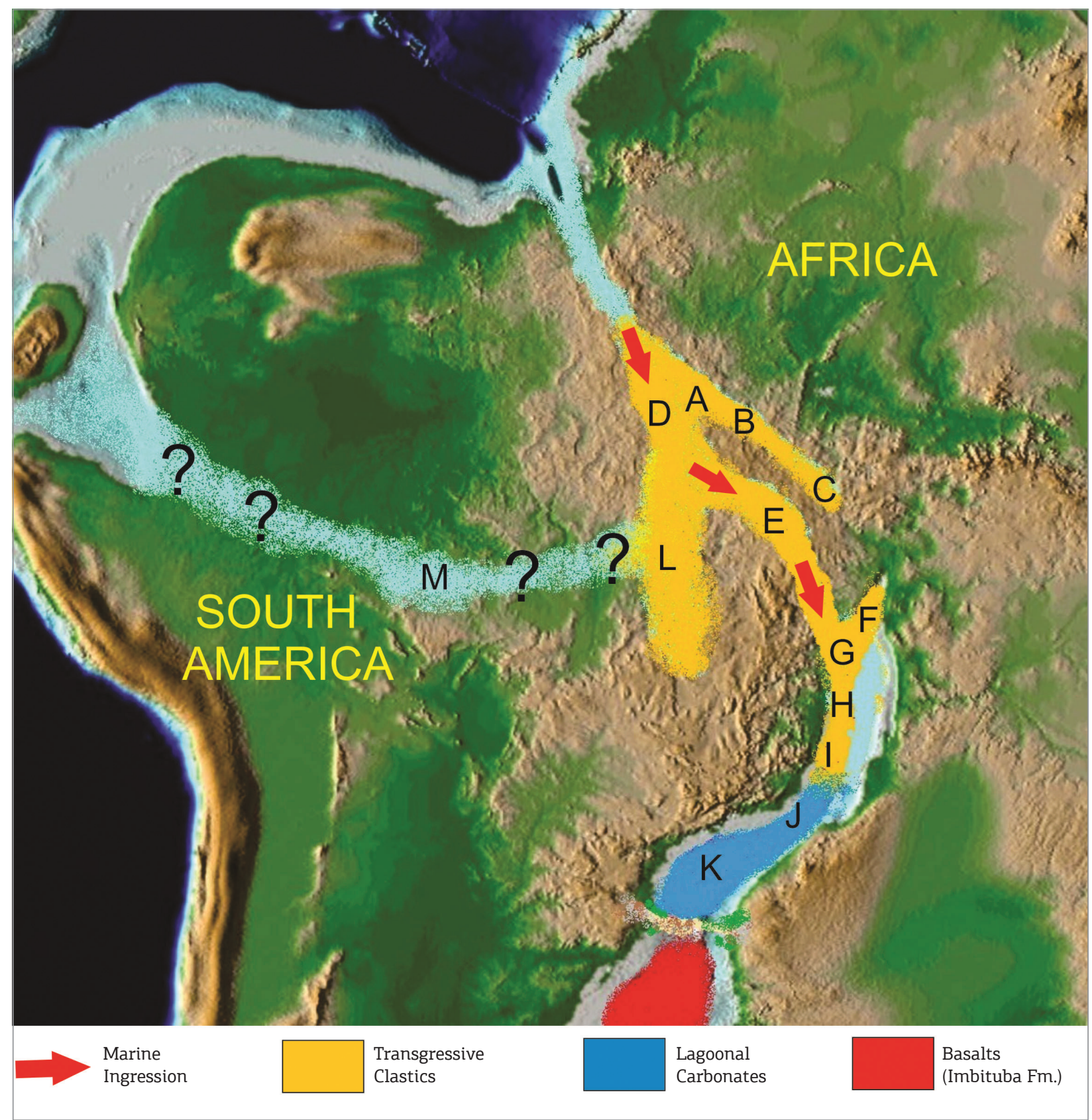

Figure 1. Aptian map modified from Scotese's (2001) reconstruction for 120 Ma showing the paleogeography immediately prior to the Aptian evaporite deposition. Key stratigraphic units: (A) Barreirinhas Basin, "Rift II" sensu Trosdtorf Jr. et al. (2008); (B) Ceará Basin, Mundaú Formation; (C) Potiguar Basin, Alagamar Formation (Canto do Amaro Member); (D) São Luís and Parnaíba basins, Grajaú Formation; (E) Araripe Basin, Rio da Batateira Formation; (F) Sergipe Basin, Muribeca Formation (Carmópolis Member); (G) Recôncavo and Tucano basins, Marizal Formation; (H) Camamu and Almada basins, Taipus-Mirim Formation; (I) Jequitinhonha, Cumuruxatiba and Espírito Santo basins, Mariricu Formation (Mucuri Member); (J) Campos Basin, Lagoa Feia Group (pre-salt section); (K) Santos Basin, Guaratiba Group (pre-salt section); (L) Sanfranciscan Basin, Areado Formation; (M) Parecis Basin, Salto das Nuvens Formation. 
northwest-southeast orientation, as depicted in the paleogeographic reconstruction by Arai (2014, Fig. 2). A compelling indication that the Aptian seaway did not extend westward from the Araripe Basin is the absence of Aptian-Albian strata in the Padre Marcos Basin, where fossiliferous sediments suggested only the presence of older (Neocomian) nonmarine strata (Carvalho 2000, 2001, 2014; Carvalho \& Viana 1996). On the other hand, the northwest-southeast seaway

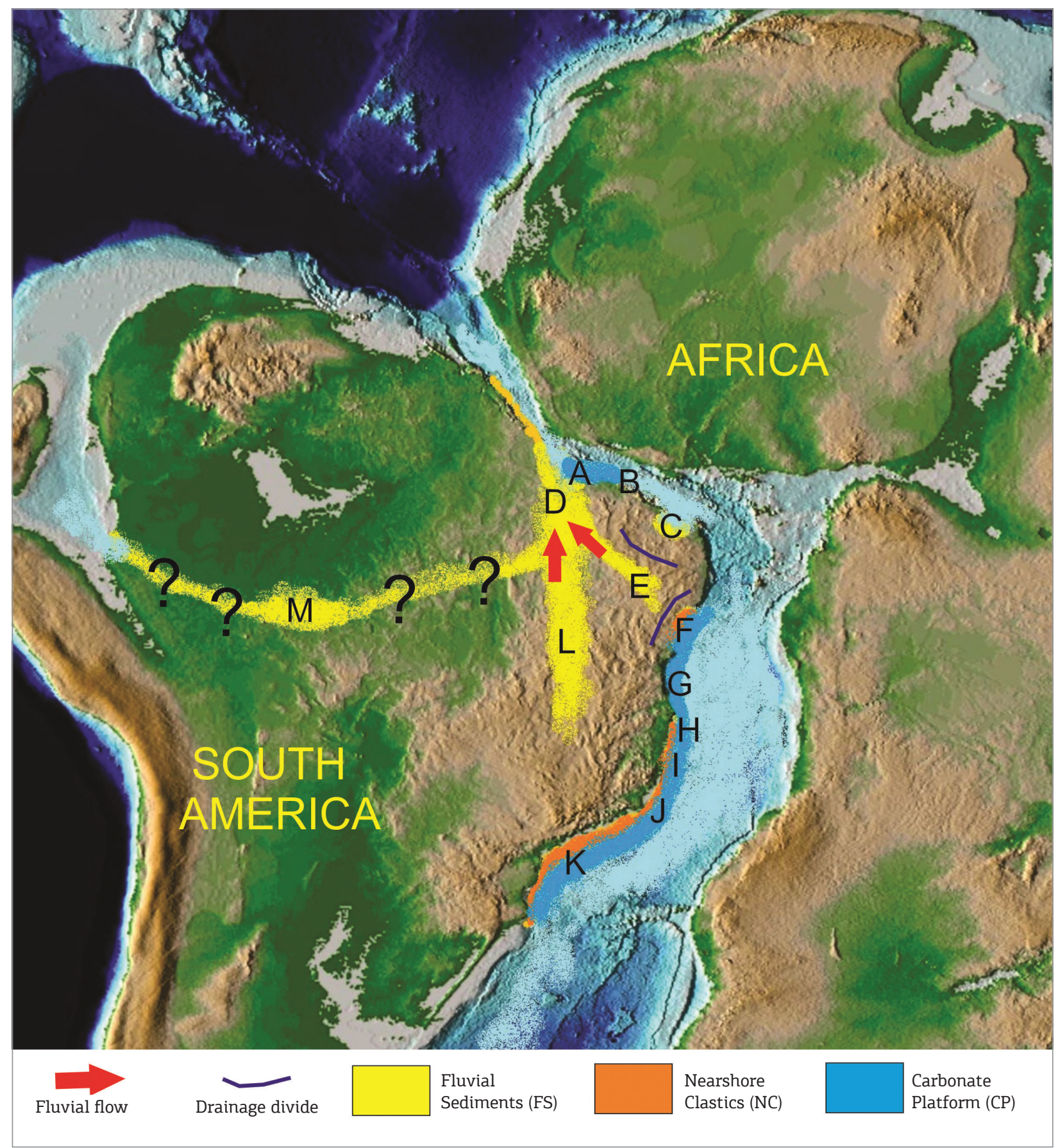

Figure 2. Albian paleogeographic map modified from Scotese's (2001) map for $108 \mathrm{Ma}$. Key stratigraphic units: (A) Barreirinhas Basin, Canárias and Caju groups [CP]; (B) Ceará Basin, Ubarana Formation; (C) Potiguar Basin, Açu Formation [FS]; (D) São Luís and Parnaíba basins, Itapecuru Group [FS]; (E) Araripe Basin, Exu Formation [FS]; (F) Sergipe Basin, Riachuelo Formation [NC, CP]; (G) Recôncavo and Tucano basins, no Albian units; (H) Camamu and Almada basins, Algodões Formation [CP]; (I) Jequitinhonha, Cumuruxatiba and Espírito Santo basins, São Mateus [NC] and Regência [CP] formations; (J) Campos Basin, Macaé Group; (K) Santos Basin, Florianópolis [NC] and Guarujá [CP] formations; (L) Sanfranciscan Basin, Grupo Urucuia [FS]; (M) Parecis Basin, Utiariti Formation [FS]. 
direction has been reinforced by more recent discoveries in the region of Brejo (northeast Maranhão State); here, fossil assemblages very similar those of the Romualdo Member have been identified (Lindoso 2012; Lindoso et al. 2013a, b).

It should also be recalled that the Aptian Northeast Brazilian Seaway was not a direct consequence of the continental breakup, being unrelated directly to the South Atlantic opening. The primitive South Atlantic has been compared with the Red Sea (e.g., Wardlaw \& Nicholls 1972, Berggren \& Hollister 1974, Azevedo 2004), but this model is valid only for the Albian-Cenomanian of the basins of the Brazilian Eastern Continental Margin (basins indicated by F, G, H, I, J and K in Fig. 2). For the Brazilian TransNortheast Seaway, the most relevant present-day analogue is the Strait of Dover, situated between England and France.

The extension of the seaway, including the Parecis Basin, is highly speculative. I have already conceded the uncertainty, by placing an interrogation mark (?) on paleogeographic-reconstruction maps including seaways pertaining to the Parecis Basin (Arai 2011, Fig. 6; Arai 2014, Fig. 2).
Moreover, the absence of affirmative evidence does not imply that there is proven negative evidence. A classic example of this is the case of the Old Red Sandstone (ORS) which, for over a century, has been considered as having a continental origin (Wikipedia 2014). More recently, several researchers have identified ORS strata deposited under marine influence (e.g., Allen 1974, Scheckler 1986, Richardson 2007). Another example is the case of the Barreiras Group (Neogene of the Brazilian coastal belt, from Pará to Rio de Janeiro) which, for several decades, has been regarded as continental (mainly fluvial/alluvial) in origin (e.g., Oliveira \& Leonardos 1940, p. 409; Bigarella 1975, p. 368; Mendes \& Petri 1971, p. 143; Petri \& Fúlfaro 1983, p. 441). This viewpoint changed radically, when Arai et al. (1988) reported marine fossils in Miocene strata of the Barreiras Group. Furthermore, the evidence of marine sedimentation came to be recognized also from sedimentary structures generated by tidal flows (Rossetti et al. 1989; Costa et al. 1993; Truckenbrodt et al. 1994) and from ichnofossils produced by neritic organisms (Costa et al. 1993; Rossetti 2006).

\section{REFERENCES}

Allen J.R.L. 1974. Sedimentology of the Old Red Sandstone (SiluroDevonian) in the Clee Hills area, Shropshire, England. Sedimentary Geology, 12:73-167.

Arai M. 2011. Paleogeografia do Atlântico Sul no Aptiano: um novo modelo a partir de dados micropaleontológicos recentes. Boletim de Geociências da Petrobras, 17(2):331-351 (issue cover date: 2009).

Arai M. 2014. Aptian/Albian (Early Cretaceous) paleogeography of the South Atlantic: a paleontological perspective. Brazilian Journal of Geology, 44(2):339-350,

Arai M., Uesugui N., Rossetti D.F., Góes A.M. 1988. Considerações sobre a idade do Grupo Barreiras no nordeste do estado do Pará. In: $35^{\circ}$ Congresso Brasileiro de Geologia. Belém, Anais, v.2, p. 738-752.

Assine M.L. 1994. Paleocorrentes e paleogeografia na Bacia do Araripe, Nordeste do Brasil. Revista Brasileira de Geociências, 24(4):223-232.

Assine M.L. 2008. Bacia do Araripe. Boletim de Geociências da Petrobras, 15(2):371-389 (issue cover date: 2007).

Azevedo R.L.M. 2004. Paleoceanografia e a evolução do Atlântico Sul no Albiano. Boletim de Geociências da Petrobras, 12(2):231-249.

Berggren W.A. \& Hollister C.D. 1974. Paleogeography, paleobiogeography, and the history of circulation in the Atlantic Ocean. In: Studies on Paleo-oceanography. Tulsa, SEPM, p. 126-186 (SEPM Special Publications, 20).

Bigarella J.J. 1975. The Barreiras Group in Northeastern Brazil. Anais da Academia Brasileira de Ciências, 47(Suplemento):365-393.

Carvalho I.S. 2000. Conchostráceos da Bacia de Padre Marcos (Cretáceo Inferior), Estado do Piauí. In: $1^{\circ}$ Simpósio Brasileiro de Paleoartropodologia. Ribeirão Preto, Abstracts, p. 101.

Carvalho I.S. 2001. Conchostráceos da Bacia de Padre Marcos (Cretáceo Inferior), Estado do Piauí, Brasil. Acta Geologica Leopoldensia, XXIV(52/53):349-357.
Carvalho I.S. 2014. Conchostráceos das bacias interiores do Nordeste brasileiro: indicadores climáticos do Cretáceo Inferior. In: Carvalho I.S., Garcia M.J., Lana C.C., Strohschoen Jr. O. (eds.) Paleontologia: Cenários de Vida. Rio de Janeiro, Editora Interciência, v. 5, p. 121-134.

Carvalho I.S. \& Pedrão E. 1998. Brazilian theropods from the Equatorial Atlantic Margin: behavior and environmental setting. Gaia, 15:369-378.

Carvalho I.S. \& Viana M.S.S. 1996. A Bacia de Padre Marcos (Cretáceo Inferior, Estado do Piauí) e sua icnofauna dinossauriana. In: 39 Congresso Brasileiro de Geologia. Salvador, Anais, v.2, p. 265-267.

Costa J.B.S., Borges M.S., Bemerguy R.L., Fernandes J.M.G., Costa Jr. P.S., Costa M.L. 1993. Evolução cenozoica da região de Salinópolis, nordeste do estado do Pará. Geociências, São Paulo, 12(2): 373-396.

Cox C.B. \& Moore P.D. 2000. Biogeography: an ecological and evolutionary approach. London, Blackwell Science, 6th. edition, 298 p.

Ferreira N.N, Ferreira E.P., Carvalho I.S., Carvalho M.A. 2011. Análise sedimentológica e palinológica dos depósitos do afloramento Querru, Formação Itapecuru, Bacia do Parnaíba. In: Carvalho I.S., Garcia M.J., Lana C.C., Strohschoen Jr. O. (eds.) Paleontologia: Cenários de Vida. Rio de Janeiro, Editora Interciência, v. 3, p. 93-103.

Ferreira N.N, Ferreira E.P., Ramos R.R.C., Carvalho I.S. 2016. Palynological and sedimentary analysis of the Igarapé Ipiranga and Querru 1 outcrops of the Itapecuru Formation (Lower Cretaceous, Parnaíba Basin), Brazil. Journal of South American Earth Sciences, 66:15-31.

Lindoso R.M. 2012. Paleobiota dos depósitos calcários de Brejo, Maranhão (Formação Codó, Bacia do Parnaiba), Nordeste do Brasil. MS Dissertation, Universidade Federal do Rio de Janeiro, Rio de Janeiro, $73 \mathrm{p}$. 
Lindoso R.M., Carvalho I.S., Mendes I.D. 2013a. An isopod from the Codó Formation (Aptian of the Parnaíba Basin), Northeastern Brazil. Brazilian Journal of Geology, 43(1):16-21.

Lindoso R., Maisey J., Carvalho I. 2013b. The paleoichthyofauna from the Codó Formation (Aptian of the Parnaíba Basin), Northeastern Brazil. In: $73^{\text {rd }}$ Meeting of the Society of Vertebrate Paleontology. Los Angeles, Programs and Abstracts, p. 162.

Lomolino M.V., Riddle B.R., Brown J.H. 2006. Biogeography. Sunderland, Sinauer Associates Inc., 3rd. edition, 846 p.

Mendes J.C. \& Petri S. 1971. Geologia do Brasil. Rio de Janeiro, Instituto Nacional do Livro/Ministério da Educação e Cultura, 207 p. (Enciclopédia Brasileira, Biblioteca Universitária, Geociências/ Geologia, Tomo 9).

Oliveira A.I. \& Leonardos O.H. 1940. Geologia do Brasil. Rio de Janeiro, Comissão Brasileira dos Centenários de Portugal, 472 p., 36 plates.

Petri S. \& Fulfaro V.J. 1983. Geologia do Brasil (Fanerozoico). In: Queiroz T.A. (ed). São Paulo, T.A. Queiroz/Editora da Universidade de São Paulo, 631 p.

Richardson J.B. 2007. Cryptospores and miospores, their distribution patterns in the Lower Old Red Sandstone of the Anglo-Welsh Basin, and the habitat of their parent plants. Bulletin of Geosciences, Czech Geological Survey, 82(4):355-364.

Rossetti D.F. 2006. Evolução sedimentar miocênica nos estados do Pará e Maranhão. Revista do Instituto de Geociências USP, 6(2):7-18.
Rossetti D.F., Truckenbrodt W. Góes A.M. 1989. Estudo paleoambiental e estratigráfico dos sedimentos Barreiras e PósBarreiras na Região Bragantina, nordeste do Pará. Boletim do Museu Paraense Emílio Goeldi, série Ciências da Terra, 1(1):25-74.

Scheckler S.E. 1986. Old Red Continent facies in the Late Devonian and Early Carboniferous of Appalachian North America. Annales de la Société Géologique de Belgique, 109:223-236.

Scotese C.R. 2001. Atlas of Earth History. Arlington, PALEOMAP Project, $52 \mathrm{p}$.

Trosdtorf Jr. I., Zalán P.V., Figueiredo J.J.P., Soares E.F. 2008. Bacia de Barreirinhas. Boletim de Geociências da Petrobras, 15(2):331-339 (issue cover date: 2007).

Truckenbrodt W., Nogueira A.C.R., Góes A.M., Arai M. 1994. Conteúdo fossilífero e estruturas sedimentares nos sedimentos Barreiras, NE do Pará. In: $38^{\circ}$ Congresso Brasileiro de Geologia. Camboriú, Boletim de Resumos Expandidos, v. 3, p. 210-211.

Wardlaw N.C. \& Nicholls G.D. 1972. Cretaceous evaporites of Brazil and West Africa and their bearing on the theory of continental separation. In: 24 $4^{\text {th }}$ International Geological Congress. Montreal, Proceedings, v. 6, p. 43-55

Wikipedia 2014. Old Red Sandstone. Available at https://simple. wikipedia.org/wiki/Old_Red_Sandstone. Cited in 2016 Fev 01.

Arquivo digital disponível on-line no site www.sbgeo.org.br 